\title{
Synthesis and characterization of novel metal complexes of (pentulose- $\gamma$-lactone-2,3-enedibenzoate barbituric acid) with some metal ions
}

\author{
Abdul-Jabbar A. Mukhlis, * Basima M. Sarhan,* \\ Rasmia M. Rumez* \\ Received 2, July, 2012 \\ Accepted 9, December, 2012
}

\begin{abstract}
:
New (pentulose- $\gamma$-lactone-2,3-enedibenzoate barbituric acid) (L) have been synthesized by reaction of (5-C-dimethyl malonyl-pentulose- $\gamma$-lactone-2,3enedibenzoate) with urea in alkaline media (sodium methoxide). $\left(\mathrm{Ca}^{+2}, \mathrm{Co}^{+2}, \mathrm{Ni}^{+2}\right.$, $\mathrm{Cu}^{+2}, \mathrm{Zn}^{+2}, \mathrm{Cd}^{+2}$ and $\mathrm{Hg}^{+2}$ ) complexes of (pentulose- $\gamma$-lactone-2,3-enedibenzoate barbituric acid) (L) have been prepared and characterized by $\left({ }^{1} \mathrm{H}\right.$ and $\left.{ }^{13} \mathrm{CNMR}\right)$, FTIR, (U.V-Vis) spectroscopy, Atomic absorption spectrophotometer (A.A.S), Molar conductivity measurements and Magnetic moment measurements, and the following general formula has been given for the prepared complexes $\left[\mathrm{MLCl}_{2}\left(\mathrm{H}_{2} \mathrm{O}\right)\right] \cdot \mathrm{XH}_{2} \mathrm{O}$, where $\mathrm{M}=\left(\mathrm{Ca}^{+2}, \mathrm{Co}^{+2}, \mathrm{Ni}^{+2}, \mathrm{Cu}^{+2}, \mathrm{Zn}^{+2}, \mathrm{Cd}^{+2}, \mathrm{Hg}^{+2}\right), \mathrm{X}=$ five molecules with $\left(\mathrm{Cd}^{+2}\right)$ complex, $\mathrm{L}=$ (pentulose- $\gamma$-lactone-2,3-enedibenzoate barbituric acid).
\end{abstract}

Key words: dimethyl malonyl, pentulose, lactone, benzoate, barbituric acid, complexes.

\section{Introduction}

A variety of transition metal complexes with barbiturates have been prepared owing to their important roles in clinical detection and identification of drug[1-5]. Masoud[6] reported the synthesis of copper complexes with azobarbituric and azothiobarbituric acids. Also Mazharul[7] reported the synthesis of new ligands of macrocycle systems from the reaction of thiobarbituric acid with diethylenetriamine and diethyl oxalate. In this paper, properties of some new metal ions complexes with (pentulose$\gamma$-lactone-2,3-enedibenzoate barbituric acid) (L) have been prepared.

\section{Materials and Methods:}

Metal salts $\quad\left(\mathrm{CaCl}_{2} \cdot 6 \mathrm{H}_{2} \mathrm{O}\right.$,

$\mathrm{CoCl}_{2} .6 \mathrm{H}_{2} \mathrm{O}, \quad \mathrm{NiCl}_{2} \cdot 6 \mathrm{H}_{2} \mathrm{O}$,

$\mathrm{CuCl}_{2} \cdot 2 \mathrm{H}_{2} \mathrm{O}, \mathrm{ZnCl}_{2}, \mathrm{CdCl}_{2} \cdot \mathrm{H}_{2} \mathrm{O}$ and $\mathrm{HgCl}_{2}$ ) were obtained from Fluka,

Merck in high purity, Urea (Fluka), Sodium metal, Dimethyl malonate (BDH). ( ${ }^{1} \mathrm{H}$ and $\left.{ }^{13} \mathrm{CNMR}\right)$ spectra were recorded using Ultra Shield 300 $\mathrm{MHz}$, Bruker, Switzerland, at University of $\mathrm{Al}$ al-Bayt, Jordan. IR spectra (in $\mathrm{KBr}$ discs) were recorded on Shimadzu FT Infrared spectrophotometer. The (U.V-Vis) were recorded using (Shimadzu U.VVis 160A), (U.V-Vis) spectrophotometer in dimethyl sulphoxide solution $\left(10^{-3} \mathrm{M}\right)$. Metal contents of the complexes were determined by Atomic absorption technique by using Shimadzu (AA680G) Atomic absorption spectrophotometer. The magnetic moments $\left(\mu_{\text {eff }}\right.$ B.M) were calculated on Faraday method by using (Balance Magnetic Susceptibility Model MSBMKT). Melting points were determined by using (Stuart-melting point apparatus). Conductivity

*Department of Chemistry, College of Education / Ibn-Al-Haitham, Baghdad University 
measurements were carried out using Philips PW.Digital.

\section{Synthesis of ligand, (pentulose- $\gamma$ -}

\section{lactone-2,3-enedibenzoate barbituric} acid)

1- Dry urea (15.5mmol) was added to solution of sodium methoxide (30.9mmol of sodium metal in absolute methanol $(20 \mathrm{ml}))$, stirring at room temperature for 1 hour.

2- Solution of (5-C-dimethyl malonylpentulose- $\gamma$-lactone-2,3-

enedibenzoate)[8] (A) $(10.3 \mathrm{mmol})$ in absolute methanol $(30 \mathrm{ml})$ was added, stirring was continued at room temperature for 48 hours. The solvent was evaporated; the combined residue was washed with hot absolute ethanol to give the white crystals, scheme (1).

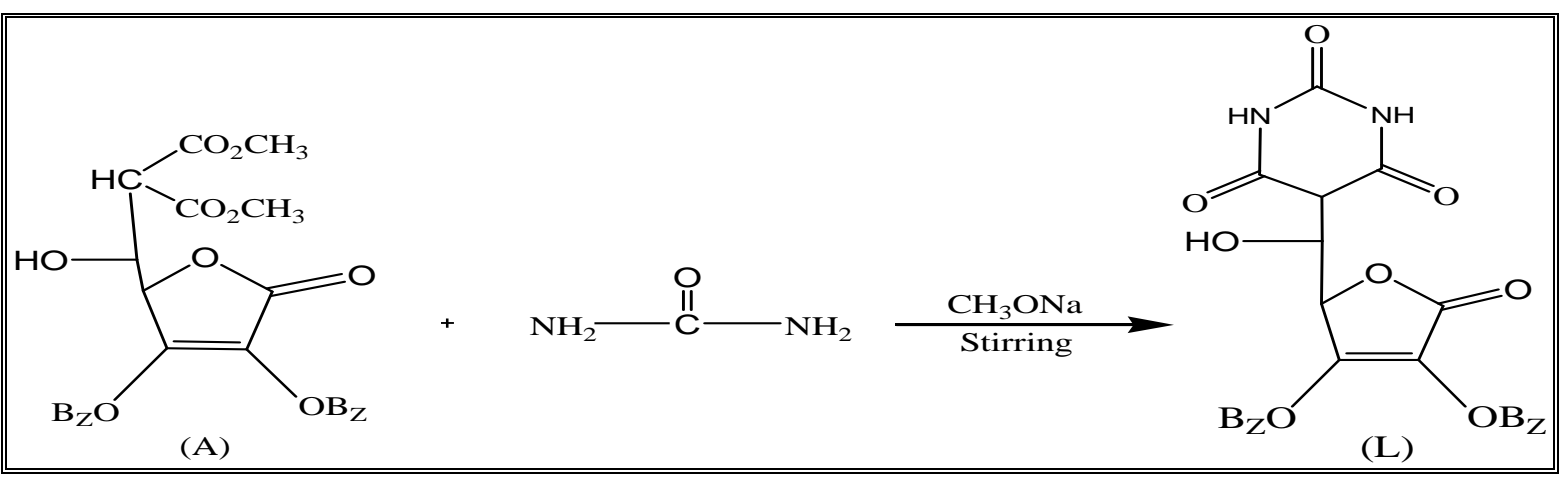

Scheme (1) the synthesis route of ligand (L)

\section{Synthesis of complexes}

Addition of ethanol solution of the metal salts $\left(\mathrm{Ca}^{+2}, \mathrm{Co}^{+2}, \mathrm{Ni}^{+2}, \mathrm{Cu}^{+2}, \mathrm{Z}^{+2}\right.$, $\mathrm{Cd}^{+2}$ and $\mathrm{Hg}^{+2}$ ) (1mmol) to solution of (L) (1mmol) distilled water. The mixture was stirring for 3 hours at room temperature, the resulting precipitates were filtered, washed and recrystallized from ethanol and dried in an oven at $50^{\circ} \mathrm{C}$.

\section{Results and Discussion:}

The isolated complexes were crystalline solids, soluble in some of common solvents such as dimethyl formamide (DMF), dimethyl sulphoxide (DMSO). The conductivity measurements in DMSO indicated the non-electrolyte behavior; Table (1) includes the physical properties. The analytical data confirmed the $(1: 1)$ (Metal:Ligand) composition of the complexes. The magnetic measurements ( $\mu_{\mathrm{eff}}$ B.M) for the complexes are also listed in Table (1). 
Table (1) Physical properties of ligand and its complexes

\begin{tabular}{|c|c|c|c|c|c|}
\hline Formula & Colour & $\begin{array}{l}\text { M.p }{ }^{\circ} \mathrm{C} \text { or } \\
\text { dec. }\end{array}$ & $\begin{array}{l}\text { Metal \% } \\
\text { Found } \\
\text { (Calc.) }\end{array}$ & $\begin{array}{l}\text { Molar conductivity } \\
\left({\left.\mathrm{S} . \mathrm{cm}^{2} \mathrm{~mole}^{-1}\right) \text { in }}^{\text {DMSO }\left(10^{-3} \mathrm{M}\right)}\right.\end{array}$ & $\begin{array}{c}\mu_{\mathrm{eff}} \\
\text { (B.M) }\end{array}$ \\
\hline $\begin{array}{c}\mathrm{C}_{23} \mathrm{H}_{16} \mathrm{O}_{10} \mathrm{~N}_{2} \\
{[\mathrm{~L}]} \\
\end{array}$ & White & 210(dec.) & - & 3.42 & - \\
\hline$\left[\mathrm{CaLCl}_{2}\left(\mathrm{H}_{2} \mathrm{O}\right)\right]$ & Yellow & 185(dec.) & $\begin{array}{c}7.81 \\
(6.58) \\
\end{array}$ & 20.1 & 0.00 \\
\hline$\left[\mathrm{CoLCl}_{2}\left(\mathrm{H}_{2} \mathrm{O}\right)\right]$ & Brown & 230(dec.) & $\begin{array}{l}10.44 \\
(9.38) \\
\end{array}$ & 14.1 & 4.35 \\
\hline$\left[\mathrm{NiLCl}_{2}\left(\mathrm{H}_{2} \mathrm{O}\right)\right]$ & Green & 220 (dec.) & $\begin{array}{l}10.15 \\
(9.35) \\
\end{array}$ & 14.37 & 3.03 \\
\hline$\left[\mathrm{CuLCl}_{2}\left(\mathrm{H}_{2} \mathrm{O}\right)\right]$ & Blue & 190(dec.) & $\begin{array}{c}10.12 \\
(10.04) \\
\end{array}$ & 21 & 1.72 \\
\hline$\left[\mathrm{ZnLCl}_{2}\left(\mathrm{H}_{2} \mathrm{O}\right)\right]$ & Yellow & 220(dec.) & $\begin{array}{c}10.22 \\
(10.30) \\
\end{array}$ & 18.02 & 0.00 \\
\hline$\left[\mathrm{CdLCl}_{2}\left(\mathrm{H}_{2} \mathrm{O}\right)\right] .5 \mathrm{H}_{2} \mathrm{O}$ & Yellow & 240(dec.) & $\begin{array}{c}14.80 \\
(14.57) \\
\end{array}$ & 13.02 & 0.00 \\
\hline$\left[\mathrm{HgLCl}_{2}\left(\mathrm{H}_{2} \mathrm{O}\right)\right]$ & Yellow & 200(dec.) & $\begin{array}{c}26.75 \\
(26.06)\end{array}$ & 16.88 & 0.00 \\
\hline
\end{tabular}

\section{Spectral studies}

${ }^{1} \mathrm{H}$ and ${ }^{13} \mathrm{CNMR}$ spectra studies of the ligand (L):-
A) ${ }^{1}$ HNMR spectrum for the ligand
(L)

The ${ }^{1}$ HNMR spectrum of (L), Fig. (1) showed the following signals: doublet (d) at $\delta(3) \mathrm{ppm}$ for $(1 \mathrm{H}, \mathrm{CH}$ malonate), doublet (d) at $\delta(4.70-4.78)$ ppm for $\left(1 \mathrm{H}\right.$, lactone ring $\left.\mathrm{H}_{4}\right)$, and multiplet $(\mathrm{m})$ at $\delta(7.25-7.73) \mathrm{ppm}$ for aromatic protons.

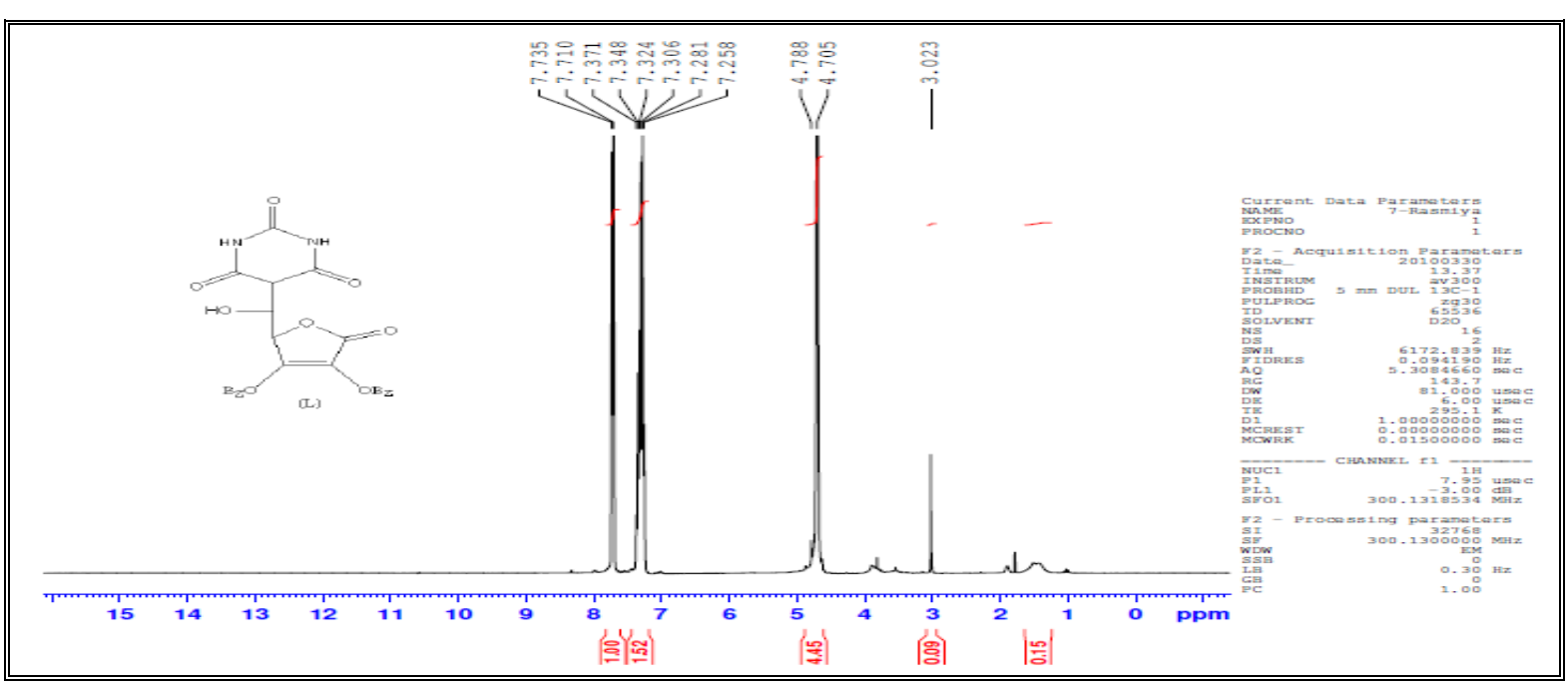

Fig. (1) ${ }^{1}$ HNMR spectrum of ligand (L)

B) ${ }^{13}$ CNMR spectrum for the ligand

(L)

The ${ }^{13}$ CNMR spectrum of (L), Fig.

(2) showed the following signals: signal at $\delta(177.53) \mathrm{ppm}$ for carbon $(\mathrm{C}=\mathrm{O})$ in $(\mathrm{HNCONH})$, signal at $\delta(175.65) \mathrm{ppm}$ for carbon $(\mathrm{C}=\mathrm{O})$ in $(\mathrm{CHCONH})$, signal at $\delta(164.53) \mathrm{ppm}$ for carbon $(\mathrm{C}=\mathrm{O})$ of the ester, lactone 
ring, signal at $\delta(136.14) \mathrm{ppm}$ for $\mathrm{C}-3$, signal at $\delta(131.63) \mathrm{ppm}$ for $\mathrm{C}-2$, signals at $\delta(131.24-127.85) \mathrm{ppm}$ for aromatic carbons, signal at $\delta(61.24)$ ppm for C-4, and signal at $\delta(47.85)$ ppm for C-5 and C-6.

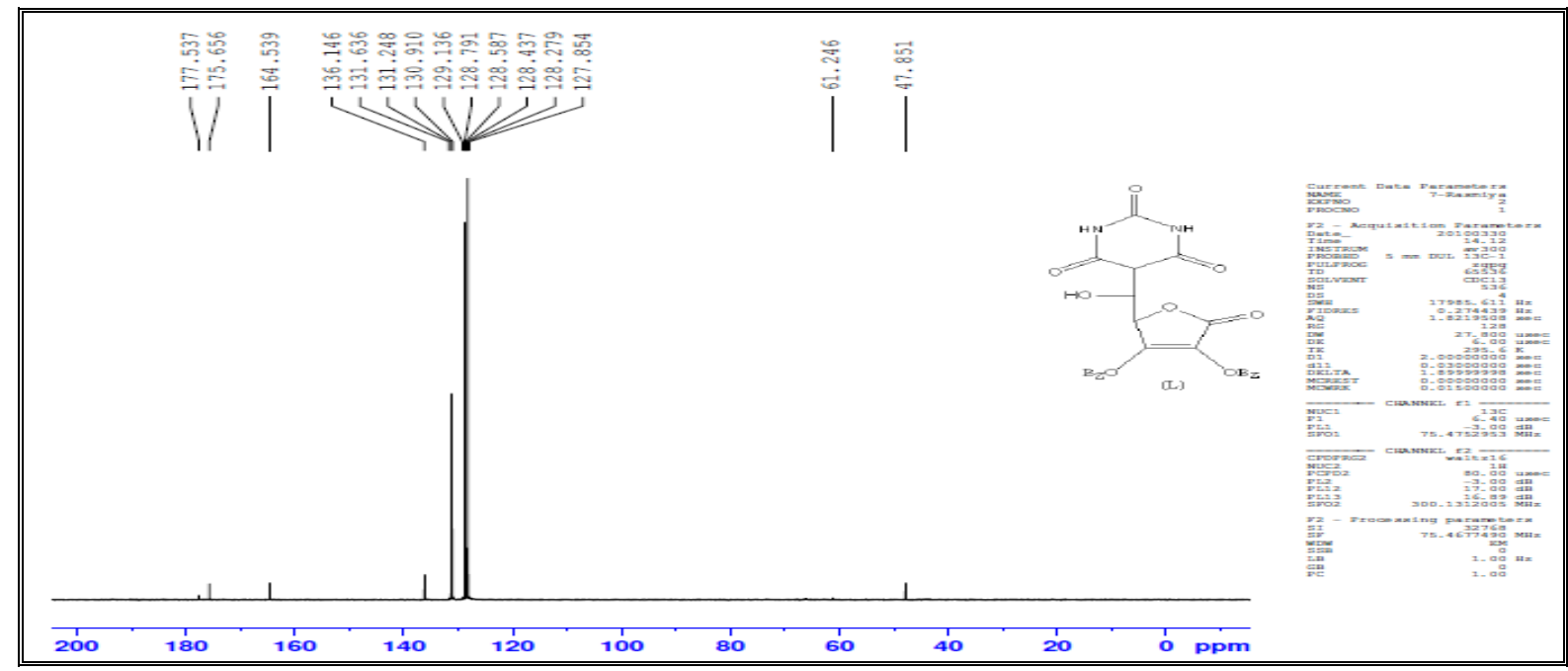

Fig. (2) ${ }^{13}$ CNMR spectrum of ligand (L)

\section{Infrared spectra}

The important infrared spectra data of ligand (L) and its complexes are given in Table (2). The strong absorption band at $(1662) \mathrm{cm}^{-1}$ and (1627) $\mathrm{cm}^{-1}$ in the free ligand, Fig. (3) due to $v(\mathrm{C}=\mathrm{O})[9],[10]$, in the complexes spectra, this band has been found in the range between (16001593) $\mathrm{cm}^{-1}$ and (1585-1550) $\mathrm{cm}^{-1}$ shifted to lower frequencies by (62-69) $\mathrm{cm}^{-1}$ and (42-77) $\mathrm{cm}^{-1}$, which indicates the coordination of the oxygen atom at the $v(\mathrm{C}=\mathrm{O})$ group[11],[12].

In the free ligand, the band at (3471) $\mathrm{cm}^{-1}$ due to $v(\mathrm{~N}-\mathrm{H})$, the spectra of the complexes show this band about (3444-3390) $\mathrm{cm}^{-1}$ shifted to lower frequencies by $(27-81) \mathrm{cm}^{-1}[13],[14]$.

The stretching vibration band $v(\mathrm{C}$ N) observed at (1346) $\mathrm{cm}^{-1}$ in the spectrum of the free ligand, has been found in the range (1454-1400) $\mathrm{cm}^{-1}$ shifted to higher frequencies on complexes formation by $(108-54) \mathrm{cm}^{-1}$, which indicates the coordination of the ligand (L) through the nitrogen atom of the aliphatic amine[15],[16]. New bands appeared in the spectra of metal complexes at (678-470) $\mathrm{cm}^{-1}$ and (520$435) \mathrm{cm}^{-1}$ attributed to the (M-N) and (M-O) respectively[17],[18]. The bands are due to coordinate chloride ion in complexes formed with metal chloride were fall bellow the limits of our infrared spectrophotometer and could not be observed.

The spectra of complexes showed the appearance of bands in the range (871-833) $\mathrm{cm}^{-1}$ attributed to $\delta(\mathrm{OH})$, these bands confirm the coordination of the water with metal[19]. Fig. (4) showed the infrared spectrum of nickel complex. 
Table (2) the characteristic infrared of the ligand (L) and its metal complexes

\begin{tabular}{|c|c|c|c|c|c|c|}
\hline Compound & $v(\mathrm{~N}-\mathrm{H})$ & $v(C=O)$ & $v(\mathrm{C}-\mathrm{N})$ & $\delta(\mathrm{OH})$ & $\mathrm{M}-\mathrm{N}$ & $\mathrm{M}-\mathrm{O}$ \\
\hline $\begin{array}{c}\mathrm{C}_{23} \mathrm{H}_{16} \mathrm{O}_{10} \mathrm{~N}_{2} \\
{[\mathrm{~L}]}\end{array}$ & 3471(s) & $\begin{array}{l}1662(\mathrm{~s}) \\
1627(\mathrm{~m})\end{array}$ & $1346(w)$ & - & - & - \\
\hline$\left[\mathrm{CaLCl}_{2}\left(\mathrm{H}_{2} \mathrm{O}\right)\right]$ & $3414(s)$ & $\begin{array}{l}1597(\mathrm{~s}) \\
1550(\mathrm{~s})\end{array}$ & $1415(\mathrm{~s})$ & $871(s)$ & $482(\mathrm{~m})$ & $455(w)$ \\
\hline$\left[\mathrm{CoLCl}_{2}\left(\mathrm{H}_{2} \mathrm{O}\right)\right]$ & $3425(\mathrm{br})$ & $\begin{array}{l}1593(\mathrm{~s}) \\
1554(\mathrm{~s})\end{array}$ & $1415(s)$ & $837(\mathrm{~m})$ & 474(m) & $435(\mathrm{~m})$ \\
\hline$\left[\mathrm{NiLCl}_{2}\left(\mathrm{H}_{2} \mathrm{O}\right)\right]$ & $3390(\mathrm{~m} . \mathrm{b})$ & $\begin{array}{l}1597(\mathrm{~s}) \\
1550(\mathrm{~s})\end{array}$ & $1400(s)$ & $840(s)$ & $478(\mathrm{~m})$ & $451(w)$ \\
\hline$\left[\mathrm{CuLCl}_{2}\left(\mathrm{H}_{2} \mathrm{O}\right)\right]$ & 3444(s) & $\begin{array}{l}1600(\mathrm{~s}) \\
1585(\mathrm{~s})\end{array}$ & $1435(\mathrm{~m})$ & 833(s) & $509(w)$ & 489(m) \\
\hline$\left[\mathrm{ZnLCl}_{2}\left(\mathrm{H}_{2} \mathrm{O}\right)\right]$ & $3410(\mathrm{br})$ & $\begin{array}{l}1597(\mathrm{~s}) \\
1554(\mathrm{~s})\end{array}$ & 1454(m) & $844(s)$ & $532(w)$ & $509(w)$ \\
\hline$\left[\mathrm{CdLCl}_{2}\left(\mathrm{H}_{2} \mathrm{O}\right)\right] .5 \mathrm{H}_{2} \mathrm{O}$ & 3433(br) & $\begin{array}{l}1593(\mathrm{~s}) \\
1554(\mathrm{~s})\end{array}$ & $1415(\mathrm{~m})$ & $856(s)$ & $470(w)$ & 447(w) \\
\hline$\left[\mathrm{HgLCl}_{2}\left(\mathrm{H}_{2} \mathrm{O}\right)\right]$ & 3433(br) & $\begin{array}{l}1597(\mathrm{~s}) \\
1550(\mathrm{~s})\end{array}$ & 1411(s) & 844(s) & $678(\mathrm{~m})$ & $520(w)$ \\
\hline
\end{tabular}

Where: $\mathrm{s}=$ strong, $\mathrm{m}=$ medium, $\mathrm{w}=$ weak, $\mathrm{br}=$ broad

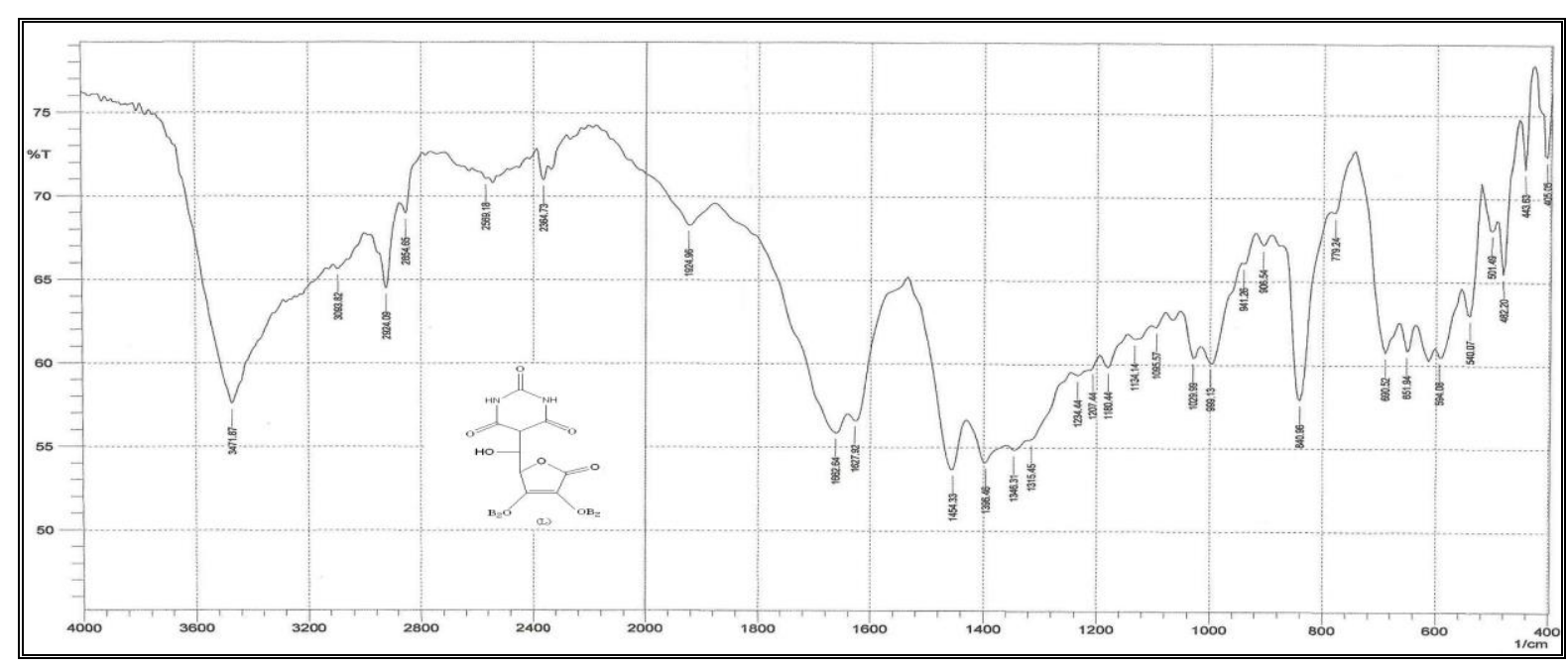

Fig. (3) Infrared spectrum of ligand (L) 


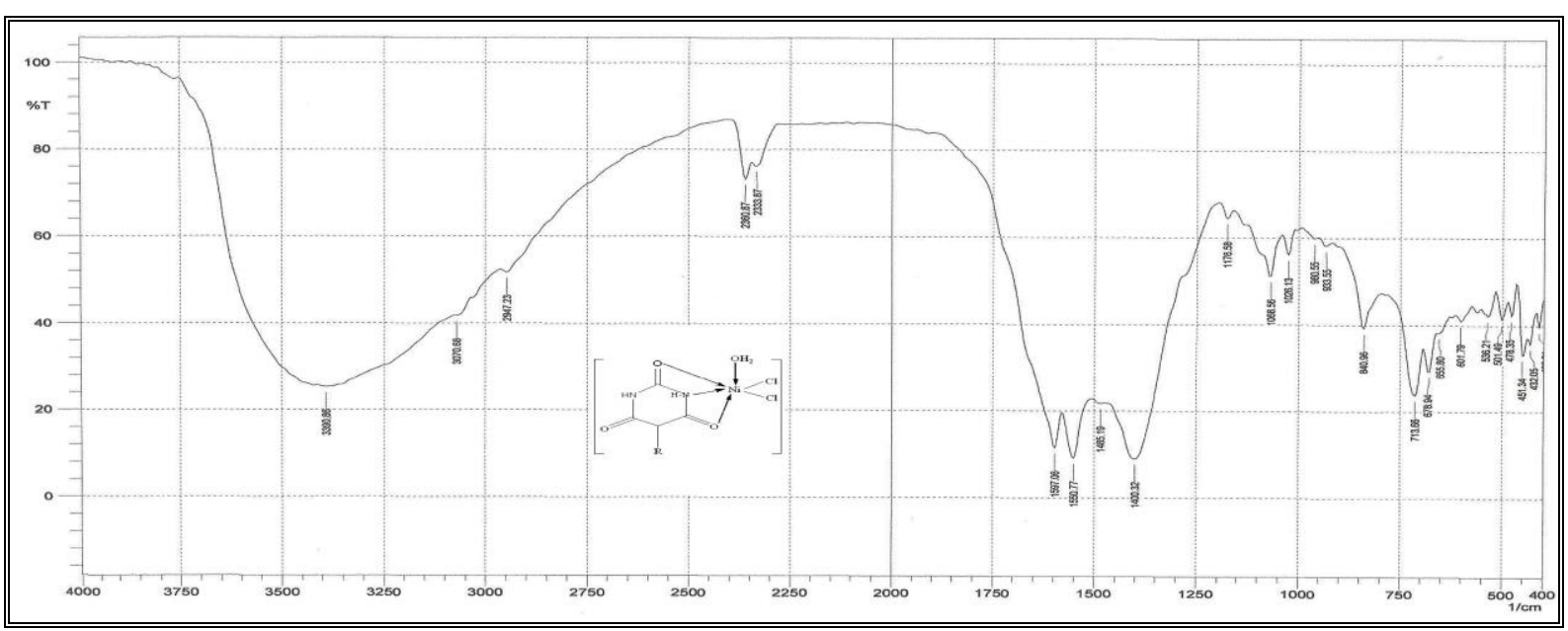

Fig. (4) Infrared spectrum of $\left[\mathrm{NiLCl}_{2}\left(\mathrm{H}_{2} \mathrm{O}\right)\right]$

\section{Electronic spectra}

The absorptions and assignments related to the ligand and their complexes are listed in Table (3). The ligand (L), Fig. (5) exhibited an absorption band in (U.V) region at (294) $\mathrm{nm}$ (34013) $\mathrm{cm}^{-1}$ which may be attributed to $\quad\left(\mathrm{n} \longrightarrow \pi^{*}\right)$ transition[9],[10].

Table (3) Electronic spectra data of (L) complexes in DMSO solvent

\begin{tabular}{|c|c|c|c|c|}
\hline Compound & $\lambda_{\max } \mathrm{nm}$ & Wave number $\mathrm{cm}^{-1}$ & $\begin{array}{c}\varepsilon_{\max } \\
\operatorname{molar}^{-1} \mathrm{~cm}^{-1}\end{array}$ & Assignment \\
\hline$[\mathrm{L}]$ & 294 & 34013 & 66 & $\mathrm{n} \longrightarrow \pi^{*}$ \\
\hline$\left[\mathrm{CaLCl}_{2}\left(\mathrm{H}_{2} \mathrm{O}\right)\right]$ & 296 & 33783 & 253 & C.T \\
\hline \multirow[t]{4}{*}[\mathrm{CoLCl}_{2}(\mathrm{H}_{2}\mathrm{O})]{} & 292 & 34246 & 83 & C.T \\
\hline & 350 & 28571 & 18 & ${ }^{4} \mathrm{~T}_{1 \mathrm{~g}}(\mathrm{~F}) \stackrel{\mathrm{V}_{3}}{\longrightarrow}{ }^{4} \mathrm{~T}_{1 \mathrm{~g}}(\mathrm{p})$ \\
\hline & 551 & 18148 & 14 & $\stackrel{\mathrm{V}_{2}}{\longrightarrow}$ \\
\hline & 804 & 12437 & 9 & ${ }^{4} \mathrm{~T}_{1 \mathrm{~g}}(\mathrm{~F}) \stackrel{\mathrm{V}_{1}}{\longrightarrow}{ }^{4} \mathrm{~T}_{2 \mathrm{~g}}$ \\
\hline \multirow[t]{4}{*}[\mathrm{NiLCl}_{2}(\mathrm{H}_{2}\mathrm{O})]{} & 290 & 34482 & 156 & C.T \\
\hline & 340 & 29411 & 25 & $\stackrel{\mathrm{V}_{3}}{\longrightarrow}-{ }^{3} \mathrm{~T}_{1 \mathrm{~g}}(\mathrm{P})$ \\
\hline & 542 & 18450 & 21 & $\mathrm{~V}_{2} \longrightarrow-3 \mathrm{~T}$ \\
\hline & 750 & 13333 & 10 & 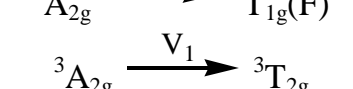 \\
\hline \multirow[t]{3}{*}[\mathrm{CuLCl}_{2}(\mathrm{H}_{2}\mathrm{O})]{} & 211 & 47393 & 89 & $\begin{array}{ll}\text { C.T } \\
\end{array}$ \\
\hline & 295 & 33898 & 598 & C.T \\
\hline & 671 & 14903 & 89 & ${ }^{2} \mathrm{E}_{\mathrm{g}} \longrightarrow{ }^{2} \mathrm{~T}_{2 \mathrm{~g}}$ \\
\hline$\left[\mathrm{ZnLCl}_{2}\left(\mathrm{H}_{2} \mathrm{O}\right)\right]$ & 299 & 33444 & 127 & I.L.C.T \\
\hline$\left[\mathrm{CdLCl}_{2}\left(\mathrm{H}_{2} \mathrm{O}\right)\right] .5 \mathrm{H}_{2} \mathrm{O}$ & 298 & 33557 & 217 & I.L.C.T \\
\hline$\left[\mathrm{HgLCl}_{2}\left(\mathrm{H}_{2} \mathrm{O}\right)\right]$ & 252 & 39682 & 54 & I.L.C.T \\
\hline
\end{tabular}




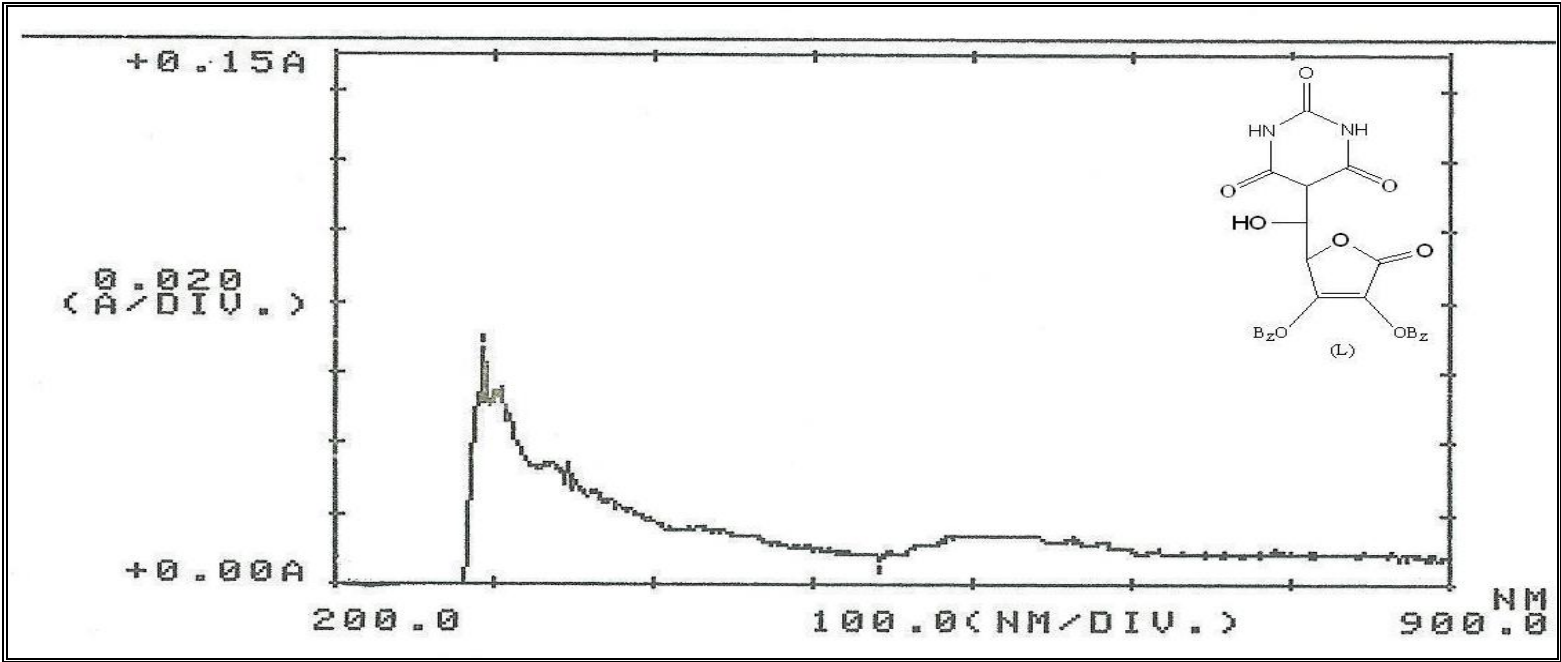

Fig. (5) Electronic spectrum of ligand (L)

The spectra of complexes

\section{- $\left[\mathrm{CoLCl}_{2}\left(\mathrm{H}_{2} \mathrm{O}\right)\right]$ complex}

The spectrum of the brown complex of $\mathrm{Co}(\mathrm{II})$, Fig. (6) exhibited the following bands at (34246) $\mathrm{cm}^{-1}$, (28571) $\mathrm{cm}^{-1}$, (18148) $\mathrm{cm}^{-1}$ and (12437) $\mathrm{cm}^{-1}$ which have been assigned to (C.T), ${ }^{4} \mathrm{~T}_{1 \mathrm{~g}}(\mathrm{~F})$ $\stackrel{\mathrm{V}_{3}}{\longrightarrow}{ }^{4} \mathrm{~T}_{1 \mathrm{~g}}(\mathrm{p}), \quad{ }^{4} \mathrm{~T}_{1 \mathrm{~g}}(\mathrm{~F}) \stackrel{\mathrm{V}_{2}}{\longrightarrow}-{ }^{4} \mathrm{~A}_{2 \mathrm{~g}}$ and respectively[20].

$$
{ }^{4} \mathrm{~T}_{1 \mathrm{~g}}(\mathrm{~F}) \stackrel{\mathrm{V}_{1}}{\longrightarrow}{ }^{4} \mathrm{~T}_{2 \mathrm{~g}}
$$

The Racah interelectronic repulsion parameter $\left(B^{\prime}\right)$ found to be $(627.2) \mathrm{cm}^{-}$ ${ }^{1}$, the ratio $\beta=B^{\prime} / B^{\circ}$ comes out to be (0.650) which indicates present covalent bond between metal ion and donor atom in the complex and these parameters are accepted for cobalt(II) octahedral complexes[21].

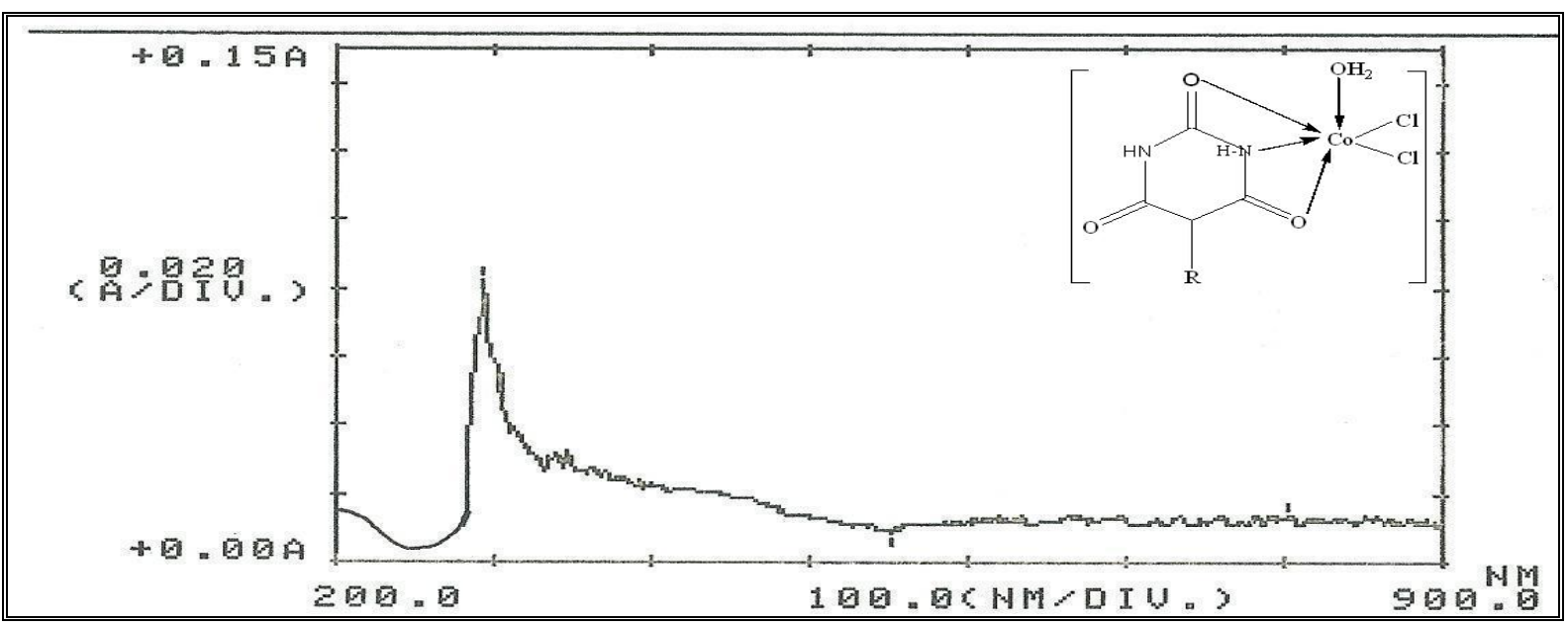

Fig. (6) Electronic spectrum of $\left[\mathrm{CoLCl}_{2}\left(\mathrm{H}_{2} \mathrm{O}\right)\right]$

\section{- $\left[\mathrm{NiLCl}_{2}\left(\mathrm{H}_{2} \mathrm{O}\right)\right]$ complex}

The spectrum of the green complex exhibited the following absorptions at
(34482) $\mathrm{cm}^{-1}$, (29411) $\mathrm{cm}^{-1},(18450)$ $\mathrm{cm}^{-1}$ and $(13333) \mathrm{cm}^{-1}$, these bands are characteristic of octahedral 
nickel(II)[22] complex and were assigned to the transitions (C.T), ${ }^{3} \mathrm{~A}_{2 \mathrm{~g}} \stackrel{\mathrm{V}_{3}}{\longrightarrow}{ }^{3} \mathrm{~T}_{1 \mathrm{~g}}(\mathrm{P})$, ${ }^{3} \mathrm{~A}_{2 \mathrm{~g}} \stackrel{\mathrm{V}_{2}}{\longrightarrow}{ }^{3} \mathrm{~T}_{1 \mathrm{~g}}(\mathrm{~F})$ and ${ }^{3} \mathrm{~A}_{2 \mathrm{~g}} \stackrel{\mathrm{V}_{1}}{\longrightarrow}{ }^{3} \mathrm{~T}_{2 \mathrm{~g}}$ respectively, and the $(B)$ found (524) $\mathrm{cm}^{-1}$ and $\beta=$

$B$ / $B$ o comes out to be $(0.50)$ which indicates present covalent bond between metal ion and donor atom in the complex.

\section{- $\left[\mathrm{CuLCl}_{2}\left(\mathrm{H}_{2} \mathrm{O}\right)\right]$ complex}

The spectrum of the blue complex of $\mathrm{Cu}$ (II) gave two bands at (47393) $\mathrm{cm}^{-1}$ and (33898) $\mathrm{cm}^{-1}$ caused by (C.T) transitions and only one absorption band was observed at (14903) $\mathrm{cm}^{-1}$ which assigned to ${ }^{2} \mathrm{E}_{\mathrm{g}} \longrightarrow{ }^{2} \mathrm{~T}_{2 \mathrm{~g}}$ transition in octahedral structurep[23],[24].

- [CaLCl$\left.{ }_{2}\left(\mathrm{H}_{2} \mathrm{O}\right)\right],\left[\mathrm{ZnLCl}_{2}\left(\mathrm{H}_{2} \mathrm{O}\right)\right]$,

$\left[\mathrm{CdLCl}_{2}\left(\mathrm{H}_{2} \mathrm{O}\right)\right] .5 \mathrm{H}_{2} \mathrm{O}$ and

[ $\left.\mathrm{HgLCl}_{2}\left(\mathrm{H}_{2} \mathrm{O}\right)\right]$

The yellow complexes $\left[\mathrm{CaLCl}_{2}\left(\mathrm{H}_{2} \mathrm{O}\right)\right], \quad\left[\mathrm{ZnLCl}_{2}\left(\mathrm{H}_{2} \mathrm{O}\right)\right]$, $\left[\mathrm{CdLCl}_{2}\left(\mathrm{H}_{2} \mathrm{O}\right)\right] .5 \mathrm{H}_{2} \mathrm{O}$ and $\left[\mathrm{HgLCl}_{2}\left(\mathrm{H}_{2} \mathrm{O}\right)\right]$ showed absorption bands at (33783) $\mathrm{cm}^{-1}$, (33444) $\mathrm{cm}^{-1}$, (33557) $\mathrm{cm}^{-1}$ and (39682) $\mathrm{cm}^{-1}$ respectively[25-28] attributed to internal ligand charge transfer.

According to these results, the structural formula of prepared complexes may be proposed in Fig. (7).

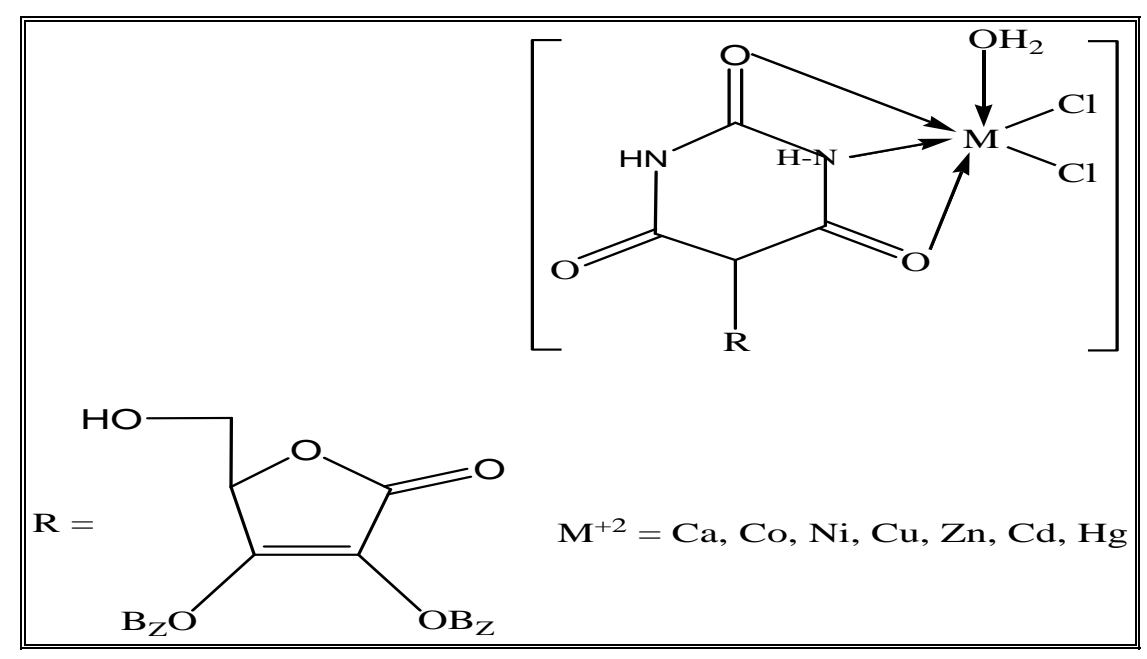

Fig. (7) the proposed structural formula of the complexes 


\section{References}

1. Tamaki, K. and Okabe, N. 1996. "Diaquabis(5isonitrosobarbiturato)cobalt(II) Dihydrate"

Acta Cryst., C52: 1124-1125.

2. Woisetschläger, O. E., Sünkel, K., Weigand, W. and Beck, W. 1999. "Metal complexes of biologically important ligands, CXVI. Addition of carbanions from barbituric acid derivatives to unsaturated hydrocarbons in cationic complexes for the organometallic labelling of barbituric acid", J. of Organometal. Chem., 584: 122-130.

3. Hsu, I.-N. and Craven, B. N. 1974. "The crystalline complex $(1: 1)$ of salicylamide and 5-ethyl-5isoamylbarbituric acid (amobarbital)", Acta Cryst., B30: 843-846.

4. Nassimbeni, L. R. and Rodgers, A. 1974. "The crystal structure of the bis(5,5'-diethylbarbiturato) bispicoline complex of zinc(II) ", Acta Cryst., B30: 1953-1965.

5. Caira, M. R., Fazakerley, G. V., Linder, P. W. and Nassimbeni, L. R. 1973. "Crystal structure of the bis $(5,5$ '-

diethylbarbiturato)bispyridine complex of copper(II) ", Acta Cryst., , B29: 2898-2904.

6. Masoud, M. S., Heiba, A. M. and Ashmawy, F. M. 1983. "Synthesis and Characterization of Barbituric and Thiobarbituric Acid Complexes", Transition Met. Chem., 8: 124-126.

7. Mazharul Haq, M. and Hashmi, A. A. 2010. "Studies on the Complexes of Transition Metal Ions with Macrocyclic Ligands Containing Nitrogen, Oxygen and Sulphur", Jamia Millia Islamia.

8. Al-Ogiady, R. M. R., , 2010. "Synthesis of New Malonate and Barbiturate Derivatives of D-
Erythroascorbic acid and their Metal Complexes" Ph. D. Thesis, University of Baghdad, College of Education / Ibn-Al-Haitham.

9. Silverstein, R. M., Bassler, G. C. and Morrill, T. C. 1981. "Spectrometric Identification of Organic Compound", $4^{\text {th }}$ Ed., John Wiley and Sons, Inc., New York.

10. Dyer, R. J. 1965. "Application of Absorption Spectroscopy of Organic Compounds" Prentice-Hall, Inc., Englwood Cliffs, N. J., London.

11. Giesbrecht, E. and Kawashita, M. 1970. "Anhydrous tetramethylurea adducts of the tripositive lanthanide perchlorates", J. Inorg. Nucl. Chem., 32: 2461-2464.

12. Jarad, A. J., Suhail, K. F. and Hussien, A. L. 2010. "Synthesis and spectroscopic studies of new heterocyclic azo dye and their complexes with selected metal ion", AL-Mustansiriya J. Sci., 21(6): 251257.

13. Trigiano, G. M., Menabue, L. and Pellaani, G. C. 1975. "Exchange interactions synthesis, spectroscopic and magnetic properties of mixedligand complexes of copper(II) with imidazole and nitrogen-protected amino acid", J. Inorg. Nucl. Chem., 47(11): 2431.

14. Kothari, V. M. and Busch, D. H. 1969. "Cobalt(III) complexes of cysteine and cysteine derivatives", Inorg. Chem., 8(11): 2276-2280.

15. Cotton, F. A. and Francis, R. 1960. "Sulfoxides as Ligands. I. A Preliminary Survey of Methyl Sulfoxide Complexes", J. Am. Chem. Soc., 82(12): 2986-2991.

16. Newman, G. and Powell, D. B. 1963. "The infra-red spectra and structures of metal-sulphite compounds", SpectroChem. Acta, 19(1): 213-224.

17. Ahuga, I. S. and Gray, A. 1971. "Morpholine complexes of mercury 
pseudohalides", Inorg. Nucl. Chem. Lett., 7(10): 937-942.

18. ChandraseKharan, M., Udupa, M. R. and Aravamudan, G. 1973. "Cysteine complexes of palladium(II) and platinum(II) ", Inorg. Chem. Acta, 7: 88.

19. Nakamoto, K. 1996. "Infrared Spectra of Inorganic and Coordination compound", $4^{\text {th }}$ Ed., John Wiley and Sons, New York.

20. Speca, A. N., Mikulski, C. M., Iaconianni, F. J. Pytlewski, L. L. and Karayannis, N. M. 1980. "Purine complexes with divalent $3 \mathrm{~d}$ metal perchlorates", Inorg. Chem., 19(11): 3491-3495.

21. Lever, A. B. P. 1968. "Inorganic Electronic Spectroscopy", Elsevier Publishing Company, Amsterdam, London, New York.

22. Drugo, R. S. 1965. "Physical Methods in Inorganic Chemistry" VanNostrand-Reinhold, New York.

23. Dichakjian, S. and Farago, M. E. 1985. "Metal Complexes of 2Amino-5-nitrothiazole", Inorg. Chem. Acta, 108: 247-259.
24. Walton, R. A. 1966. "Some Donor Properties of 1,4-Thioxane: Complexes with Transition Metal Halides" , Inorg. Chem., 5(4): 643649.

25. Selbin, J. 1965. "The chemistry of oxovanadium(IV)", Chem. Rev., 65: 153-75.

26. Bonati, F. and Ugo, R. 1967. "Organotin(IV) N,N-disubstituted dithiocarbamates", J. Organometal Chem., 10: 257-268.

27. Arjmamd, F., Parveen, S. and Mohapatra, D. K. 2012. "Synthesis, characterization of $\mathrm{Cu}$ (II) and $\mathrm{Zn}$ (II) complexes of proline-glycine and proline-leucine tetrapeptides: in vitro DNA binding and cleavage studies ", Inorg. Chem. Acta, 388(15): 1-10.

28. Naik, A. D., Beck, j., Dirtu, M. N. and Bebrone, C. 2011. "Zinc complexes with 1,2,4-triazole functionalized amino acid derivatives, synthesis, structure and $\beta$-lactamase assay", Inorg. Che $\mathrm{m}$. Acta, 368: 21-28.

\section{تحضير وتثخيص بعض المعقدات القلزية الجديدة لليكاند \\ Pentulose- $\gamma$-lactone-2,3-enedibenzoate barbituric acid الايونات القلزية}
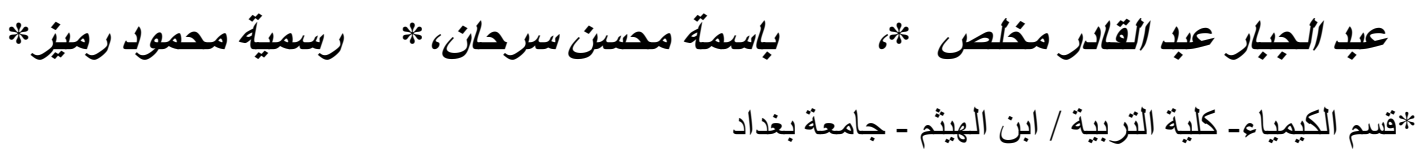

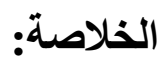

(Pentulose- $\gamma$-lactone-2,3-enedibenzoate barbituric acid) (L) حضر الليكاند الجديد

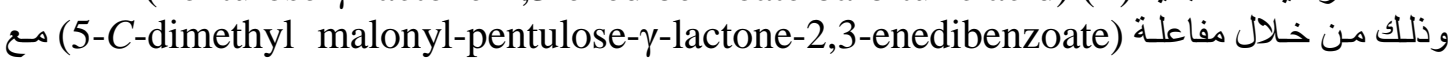

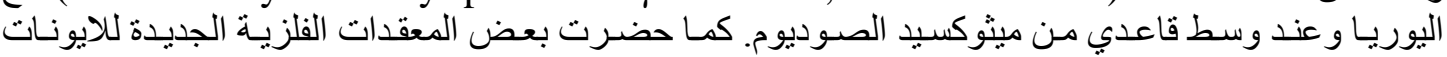

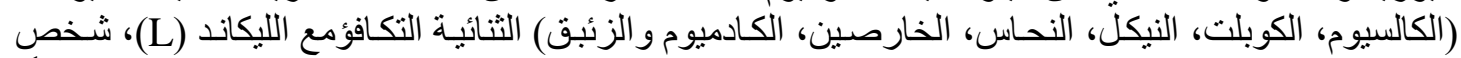

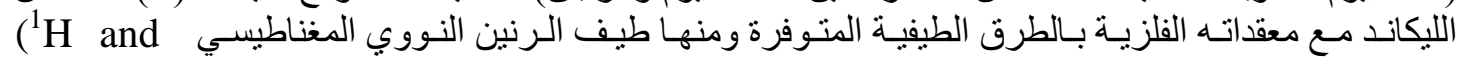
CNMR)

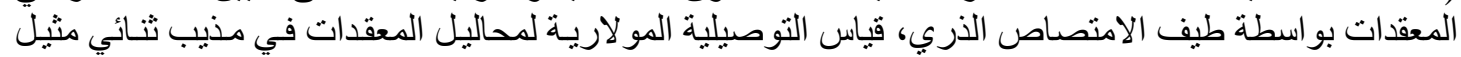

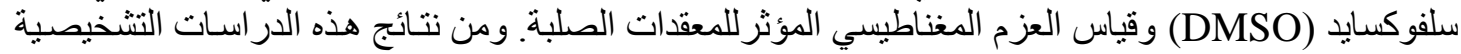
امكن اعطاء الصيغة العامـة لهذه المعقدات وكالاتي

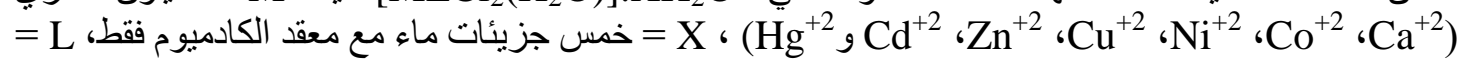
.(pentulose- $\gamma$-lactone-2,3-enedibenzoate barbituric acid) 